\title{
Degradation of 4-aminoantipyrine by electro-oxidation with a boron-doped diamond anode: Optimization by central composite design, oxidation products and toxicity
}

\author{
Lucas de Melo da Silva ${ }^{\mathrm{a}}$, Fábio Gozzi ${ }^{\mathrm{a}}$, Ignasi Sirés ${ }^{\mathrm{b}, *}$, Enric Brillas ${ }^{\mathrm{b}}$, Silvio Cesar de Oliveira ${ }^{\mathrm{a}}$, \\ Amilcar Machulek Junior ${ }^{\mathrm{a}}$ * \\ ${ }^{a}$ Institute of Chemistry, Federal University of Mato Grosso do Sul, Av. Senador Filinto Muller, 1555; CP 549, Campo Grande, MS 79074-460, Brazil

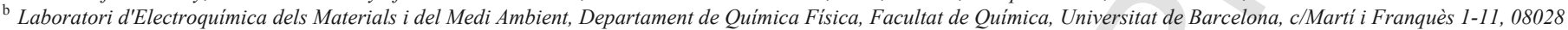 \\ Barcelona, Spain
}

\section{A R T I C L E I N F O}

\section{Article history:}

Received 13 December 2017

Received in revised form 12 February 2018

Accepted 9 March 2018

Available online xxx

Editor: Paola Verlicchi

\section{Keywords:}

Acute toxicity

4-Aminoantipyrine

BDD

Central composite design

Electrochemical oxidation

Wastewater treatment

\begin{abstract}
A B S T R A C T
Electro-oxidation with electrogenerated $\mathrm{H}_{2} \mathrm{O}_{2}\left(\mathrm{EO}-\mathrm{H}_{2} \mathrm{O}_{2}\right)$ was applied to treat acidic aqueous solutions of 4-aminoantipyrine (4-AA), a persistent drug metabolite of dipyrone, in sulfate medium. Trials were made using a boron-doped diamond anode in the presence of $\mathrm{H}_{2} \mathrm{O}_{2}$ electrogenerated on site. A $2^{4}$ central composite design (CCD) was employed to evaluate the effect of four independent variables, namely current density $(j)$, $\mathrm{pH}, 4-\mathrm{AA}$ concentration and electrolysis time, on the percentages of degradation and mineralization, as well as on mineralization current efficiency (MCE). Predicted responses agreed with observed values, showing linear trendlines with good $R^{2}$ and $R_{\text {adj }}^{2}$ values. The degradation was optimum at $j=77.5 \mathrm{~mA} \mathrm{~cm}^{-2}, \mathrm{pH} 3.5$ and $62.5 \mathrm{mg} \mathrm{L}^{-1}$ 4-AA, leading to $63 \%$ and $99 \%$ removal after 3 and $7 \mathrm{~min}$, respectively. For those solutions, the largest mineralization was found at $j=77.5 \mathrm{~mA} \mathrm{~cm}^{-2}$, attaining $45 \%$ abatement at $175 \mathrm{~min}$. Low MCE values were obtained in all electrolyses. An initial route for 4-AA degradation is proposed based on one dimer and eleven aromatic and aliphatic intermediates detected in the treated solutions at $\mathrm{pH} 3.5$ by LC-MS. The initial $62.5 \mathrm{mg} \mathrm{L}^{-1}$ solution at $\mathrm{pH} 3.5$ presented acute toxicity on Artemia salina larvae, with $\mathrm{LC}_{50}=13.6 \mathrm{mg} \mathrm{L}^{-1}$, being substantially reduced after 3 and $7 \mathrm{~min}$ of $\mathrm{EO}-\mathrm{H}_{2} \mathrm{O}_{2}$ at $j=77.5 \mathrm{~mA} \mathrm{~cm}^{-2}$ due to the formation of less toxic derivatives.
\end{abstract}

\section{Introduction}

Drugs and their metabolites are persistent organic pollutants (POPs) in the aquatic environment since they cannot be removed efficiently in conventional urban wastewater treatment plants (Gómez et al., 2008; Prieto-Rodríguez et al., 2013; Campos-Mañas et al., 2017). They are considered as emerging pollutants, not yet regulated, and their presence as traces in water streams causes great concern because of their potential harmful effects on animals and humans (Brillas and Sirés, 2015; Ebele et al., 2017). Among these chemicals, pyrazolone derivatives like antipyrines and, specially, dipyrone (metamizole) are widely prescribed as analgesics and anti-inflammatory drugs. Up to four metabolites of dipyrone have been detected in sewage treatment systems, being 4-aminoantipyrine (4-AA, $\mathrm{C}_{11} \mathrm{H}_{13} \mathrm{~N}_{3} \mathrm{O}, M=203.24 \mathrm{~g} \mathrm{~mol}^{-1}$ ) predominant with contents ranging between $20 \mathrm{ngL}^{-1}$ and $27 \mu \mathrm{gL}^{-1}$ (Prieto-Rodríguez et al., 2013; Campos-Mañas et al., 2017). 4-AA exhibits biological activity, is applied to the treatment of viral diseases (Hu et al., 2010) and forms stable complexes with hemoglobin to reduce blood flow (Gowda et al., 2015). However, despite these benefits, pyrazolones are suspect of causing suppression of immune system (i.e., agranulocytosis) (Santos et al., 2010). Several works have reported the degradation of 4-AA by

\footnotetext{
* Corresponding authors.

Email addresses: i.sires@ub.edu (I. Sirés); machulekjr@gmail.com (A.M. Junior)
}

ozonation (Muñoz et al., 2009) and advanced oxidation processes (AOPs) such as UV/ $\mathrm{H}_{2} \mathrm{O}_{2}$ (Gómez et al., 2008) and photoelectrocatalysis with a $\mathrm{TiO}_{2} / \mathrm{ITO}$ anode (Li et al., 2013). AOPs are eco-friendly technologies that involve the generation of reactive oxygen species (ROS) like the strong oxidant hydroxyl radical ( $\mathrm{OH})$, which can destroy many organics including drugs and their metabolites that tend to be resistant to conventional methods (Brillas and Sirés, 2015; Gligorovski et al., 2015; Cavalcante et al., 2016; Da Silva et al., 2016). However, there exists no previous information on the ability of a powerful electrochemical AOP (EAOP) like electro-oxidation (EO) to remove 4-AA from water.

EO is the most common EAOP for wastewater treatment (Panizza and Cerisola, 2009; Feng et al., 2013; Sirés et al., 2014; Moreira et al., 2017). The advantages of this method are simplicity, easy scale-up pre-eminently through modular units, no need of added of chemicals and use of the electron as clean reagent to promote the production of ROS. In EO, a high current density $(j)$ is usually supplied to the electrodes of an electrolytic cell in order to oxidize the water at the anode $\mathrm{M}$, thus producing adsorbed ${ }^{\circ} \mathrm{OH}$ on its surface (i.e., $\left.\mathrm{M}\left({ }^{\circ} \mathrm{OH}\right)\right)$. Nevertheless, the oxidation power of EO depends on the nature of the anode used, since active and non-active anodes behave very differently due to their larger or smaller $\mathrm{O}_{2}$-evolution overpotential and M- ${ }^{-} \mathrm{OH}$ interaction (Marselli et al., 2003; Guinea et al., 2009; Panizza and Cerisola, 2009; Coria et al., 2016; Steter et al., 2016). In particular, it has been found that boron-doped diamond (BDD) thin- 
films supported on solid substrates are the best anodes to develop such technology, since they are able to generate large amounts of quasi-free physisorbed $\mathrm{BDD}\left({ }^{\circ} \mathrm{OH}\right)$ from reaction (1) (Boye et al., 2002; Marselli et al., 2003; Özcan et al., 2008; Thiam et al., 2015a, 2015b):

$$
\mathrm{BDD}+\mathrm{H}_{2} \mathrm{O} \rightarrow \mathrm{BDD}\left({ }^{\bullet} \mathrm{OH}\right)+\mathrm{H}^{+}+\mathrm{e}^{-}
$$

In systems equipped with undivided electrochemical reactors, the nature of the cathode can also play an important role regarding the effectiveness of EO. Organics may undergo reductive transformations on many materials. This can be prevented by using a carbon-polytetrafluoroethylene (PTFE) air-diffusion electrode since it pre-eminently favors the two-electron reduction of $\mathrm{O}_{2}$ gas to $\mathrm{H}_{2} \mathrm{O}_{2}$ from reaction (2) (Sirés et al., 2014). This method is then called EO with electrogenerated $\mathrm{H}_{2} \mathrm{O}_{2}\left(\mathrm{EO}-\mathrm{H}_{2} \mathrm{O}_{2}\right)$ (Moreira et al., 2014; Thiam et al., 2015a, 2015b; Guelfi et al., 2017; Lanzalaco et al., 2017), characterized by the oxidation of this species at the BDD anode to yield hydroperoxyl radical via reaction (3), followed by its decomposition to $\mathrm{O}_{2}$ gas by reaction (4). In EO- $\mathrm{H}_{2} \mathrm{O}_{2}$, the weak ROS like $\mathrm{H}_{2} \mathrm{O}_{2}$ and $\mathrm{BDD}\left(\mathrm{HO}_{2}{ }^{\circ}\right)$ can attack the organic pollutants, but to a much smaller extent as compared to BDD( $\left.{ }^{\circ} \mathrm{OH}\right)$ (Thiam et al., 2015a, 2015b; Guelfi et al., 2017).

$$
\mathrm{O}_{2(\mathrm{~g})}+2 \mathrm{H}^{+}+2 \mathrm{e}^{-} \rightarrow \mathrm{H}_{2} \mathrm{O}_{2}
$$

$$
\mathrm{BDD}+\mathrm{H}_{2} \mathrm{O}_{2} \rightarrow \mathrm{BDD}\left(\mathrm{HO}_{2}^{\bullet}\right)+\mathrm{H}^{+}+\mathrm{e}^{-}
$$

$$
\operatorname{BDD}\left(\mathrm{HO}_{2}^{\bullet}\right) \rightarrow \mathrm{BDD}+\mathrm{O}_{2(\mathrm{~g})}+\mathrm{H}^{+}+\mathrm{e}^{-}
$$

This work addresses the study of the treatment of 4-AA solutions by means of EO- $\mathrm{H}_{2} \mathrm{O}_{2}$ using a stirred $\mathrm{BDD} /$ air-diffusion tank reactor. The assays were performed according to a $2^{4}$ central composite design $(\mathrm{CCD})$ in order to optimize the treatment upon elucidation of the relationship between $j, \mathrm{pH}, 4-\mathrm{AA}$ concentration ([4-AA]) and electrolysis time as independent variables. Three responses were considered, namely the degradation and mineralization percentages and the mineralization current efficiency (MCE). Primary intermediates were identified by liquid chromatography-mass spectrometry (LC-MS) and a plausible initial degradation route has been proposed. Finally, the evolution of acute toxicity was determined using the larvae of microcrustacean Artemia salina.

\section{Materials and methods}

\subsection{Reagents}

4-Aminoantipyrine (99\% purity) was obtained from Sigma-Aldrich. Ultrapure water (Millipore Milli-Q, resistivity $>18 \mathrm{M} \Omega \mathrm{cm}$ at $25^{\circ} \mathrm{C}$ ) was employed for the preparation of all synthetic 4-AA samples and analytical solutions. Catalase (10,000-50,000 units $(\mathrm{mg} \text { protein })^{-1}$ ) purchased from Sigma-Aldrich was employed to quench generated $\mathrm{H}_{2} \mathrm{O}_{2}$ before toxicity analysis. Other reagents and solvents were of analytical or HPLC grade supplied by Sigma-Aldrich and Vetec Quimica Fina.

\subsection{Electrochemical procedures}

The EO- $\mathrm{H}_{2} \mathrm{O}_{2}$ treatments were carried out with $100 \mathrm{~mL}$ of 4-AA solutions containing $0.050 \mathrm{M} \mathrm{Na}_{2} \mathrm{SO}_{4}$ as background electrolyte. The assays were performed in a one-compartment glass cell that was permanently thermostated by recirculating water at $25 \pm 1{ }^{\circ} \mathrm{C}$ through a glass jacket. The anode was a BDD thin-film electrode of $3 \mathrm{~cm}^{2}$ geometric area supplied by NeoCoat (La-Chaux-de-Fonds, Switzerland), synthesized on a single-crystal p-type Si (100) wafer. A cathode with the same geometric area was made from a carbon-PTFE air-diffusion electrode purchased from $E$-TEK (Somerset, NJ, USA). The device was mounted as explained elsewhere (Guelfi et al., 2017) and fed with compressed air at $1 \mathrm{Lmin}^{-1}$ to continuously electrogenerate $\mathrm{H}_{2} \mathrm{O}_{2}$. The interelectrode gap was approximately $1 \mathrm{~cm}$. The runs were carried out at constant $j$ provided by a Fa 3003 DC power supply from Instrutherm. Prior to first electrolysis, the electrodes were electrochemically cleaned/activated by polarization in $0.050 \mathrm{M} \mathrm{Na}_{2} \mathrm{SO}_{4}$ at $j=100 \mathrm{~mA} \mathrm{~cm}^{-2}$ for $240 \mathrm{~min}$.

\subsection{Analytical methodologies}

A Crison $2000 \mathrm{pH}$-meter was used for $\mathrm{pH}$ monitoring during the experiments. All samples were filtered with $0.45 \mu \mathrm{m}$ PTFE filters from Phenomenex once withdrawn from the solutions. The $\mathrm{H}_{2} \mathrm{O}_{2}$ content accumulated in the medium was determined from the absorbance of its complex with metavanadate using a Unicam UV-Vis spectrophotometer (Nogueira et al., 2005). The calibration curve for this method obeyed the Beer's law within the $0.2-2000 \mathrm{mg} \mathrm{L}^{-1}$ range. The concentration of $\mathrm{NH}_{4}^{+}$and $\mathrm{NO}_{3}{ }^{-}$ions in treated solutions was determined from the standard methods $\mathrm{SM} 4500-\mathrm{NH}_{3} \mathrm{C}$ (titrimetric method) and $\mathrm{SM} 4500-\mathrm{NO}_{3}{ }^{-} \mathrm{E}$, respectively (APHA, 2012).

Reversed-phase HPLC analysis of solutions for monitoring 4-AA concentration decay was performed with a Finnigan Surveyor system from Thermo Scientific, using a Zorbax Eclipse XDB-C-18 $5 \mu \mathrm{m}$ $(250 \mathrm{~mm} \times 4.6 \mathrm{~mm})$ column from Agilent Technologies and the detector set at $274 \mathrm{~nm}$. Aliquots of $25 \mu \mathrm{L}$ were injected into the above system and elution was ensured with a 60:40 (v/v) methanol/water mixture at $0.5 \mathrm{~mL} \mathrm{~min}^{-1}$ as mobile phase. Each aliquot was previously diluted sample with acetonitrile $1: 1(\mathrm{v} / \mathrm{v})$. The chromatograms exhibited a good peak for 4-AA at retention time of $6.5 \mathrm{~min}$ and its concentration was obtained with $\mathrm{LOD}=0.025 \mathrm{mg} \mathrm{L}^{-1}$.

The mineralization attained upon electrolysis of solutions was followed from the decay of their total organic carbon (TOC). This was determined by injecting fresh $50 \mu \mathrm{L}$ aliquots into a Shimadzu TOC VCPN analyzer. TOC values with $\pm 2 \%$ accuracy, $\mathrm{LOQ}=0.180 \mathrm{mg} \mathrm{L}^{-1}$ and $\mathrm{LOD}=0.053 \mathrm{mg} \mathrm{L}^{-1}$ were obtained.

For the identification of intermediates by LC-MS, mixtures of $5 \mathrm{~mL}$ of sample and methanol were prepared and $1 \mu \mathrm{L}$ was injected into an LC-20AD system from Shimadzu with a Kinetex C18 100A $2.6 \mu \mathrm{m}(150 \mathrm{~mm} \times 2.1 \mathrm{~mm})$ column at $50^{\circ} \mathrm{C}$ and coupled to an IES-Q-QTOF microTOFIII detector from Bruker Daltonics. It operated in positive electrospray ionization mode at spray voltage of $0.8-1.2 \mathrm{~V}$ and capillary voltage of $3500 \mathrm{~V}$, at $200^{\circ} \mathrm{C}$. The spectra were acquired within the $m / z$ 120-1300 range. Gradient elution with water (phase A) and acetonitrile (phase B), both with $0.1 \%$ formic acid, at a flow rate of $0.3 \mathrm{~mL} \mathrm{~min}^{-1}$ was employed as follows: $0-2 \mathrm{~min}$, from $0 \%$ to $3 \% \mathrm{~B} ; 2-25 \mathrm{~min}$, from $3 \%$ to $25 \% \mathrm{~B} ; 25-40 \mathrm{~min}$ from $25 \%$ to $80 \%$ $\mathrm{B}$; and $40-48 \mathrm{~min}$, from $80 \%$ to $3 \% \mathrm{~B}$.

The acute toxicity tests were carried out with larvae of microcrustacean Artemia salina after hatching of the cystic in synthetic seawater at $32 \mathrm{gL}^{-1}, \mathrm{pH} 8-9$ under aeration for $48 \mathrm{~h}$. Tests were performed 
in duplicate (5 individuals per replicate) at $20 \pm 2{ }^{\circ} \mathrm{C}$ in well cell culture plates of $3 \mathrm{~mL}$, with a photoperiod of $16 \mathrm{~h}$ light and $8 \mathrm{~h}$ dark for $96 \mathrm{~h}$ in a static system. The dead larvae were counted to obtain median lethal concentrations $\left(\mathrm{LC}_{50}\right)$, i.e., the concentrations that killed $50 \%$ of larvae within $96 \mathrm{~h}$ of exposure, which were calculated from five dilutions $(70,50,25,12.5$ and 6.25\% v/v) (Da Silva et al., 2016; El Fels et al., 2016).

\subsection{Central composite design}

A CCD modeling based on response surface methodology (RSM) was utilized to assess the effect of independent variables on different parameters that are directly related to the performance of $\mathrm{EO}-\mathrm{H}_{2} \mathrm{O}_{2}$ to remove 4-AA: percentages of degradation and mineralization, and MCE. Four independent variables were selected to model each response, namely $j\left(X_{1}\right), \mathrm{pH}\left(X_{2}\right)$, initial [4-AA] $\left(X_{3}\right)$ and electrolysis time $\left(X_{4}\right)$. Twenty-seven experiments with a $2^{4}$ factorial design using 16 cube points, 8 axial points and one triplicate at the center point were devised. The experimental matrix was generated using Statistica

Table 1

Levels of the independent variables used for the $2^{4}$ central composite design with added center point developed for the $\mathrm{EO}-\mathrm{H}_{2} \mathrm{O}_{2}$ process of $100 \mathrm{~mL}$ of 4-AA solutions in $0.050 \mathrm{M} \mathrm{Na}_{2} \mathrm{SO}_{4}$.

\begin{tabular}{llllll}
\hline Independent variable & Level & & & \\
\hline & -2 & -1 & 0 & +1 & +2 \\
\hline Current density $\left(\mathrm{mA} \mathrm{cm}^{-2}\right)$ & 10.0 & 32.5 & 55.0 & 77.5 & 100.0 \\
$\mathrm{pH}$ & 1.0 & 3.5 & 6.0 & 8.5 & 11.0 \\
{$[4-\mathrm{AA}]\left(\mathrm{mg} \mathrm{L}^{-1}\right)$} & 25.0 & 62.5 & 100.0 & 137.5 & 175.0 \\
Time for \% 4-AA degradation (min) & 1 & 3 & 5 & 7 & 9 \\
$\begin{array}{l}\text { Time for \% 4-AA mineralization } \\
\text { and for MCE (min) }\end{array}$ & 10 & 65 & 120 & 175 & 230 \\
& & & & & \\
\hline
\end{tabular}

10 software (StatSoft, Tulsa, USA). Table 1 summarizes the experimental ranges and levels of the four independent variables chosen to evaluate the $\mathrm{EO}-\mathrm{H}_{2} \mathrm{O}_{2}$ process. Note that two different time ranges were used to evaluate the three dependent parameters.

From the results obtained using the above $2^{4}$ CCD methodology and based on the corresponding RSM analysis, second-order polynomial equations were developed to describe the interaction between the dependent response and the independent (linear and quadratic) variables (Kasiri and Khata, 2011; Da Silva et al., 2016), as follows:

$$
Y=\beta_{0}+\sum_{i=1}^{k} \beta_{i} X_{i}+\sum_{1 \leq i<j}^{k} \beta_{i j} X_{i} X_{j}+\sum_{i=1}^{k} \beta_{i i} X_{i}^{2}
$$

where $k$ denotes the number of independent variables (=4), $Y$ represents the dependent variable ( $\%$ degradation, $\%$ mineralization or $\mathrm{MCE}), \beta_{0}$ is a constant, and $\beta_{i}, \beta_{i i}$ and $\beta_{i j}$ denote the regression coefficients for the linear $X_{\mathrm{i}}$, quadratic $X_{\mathrm{i}}^{2}$ and interaction $X_{\mathrm{i}} X_{\mathrm{j}}$ terms $\left(X_{\mathrm{i}}\right.$, $X_{\mathrm{i}}^{2}$ and $X_{\mathrm{i}} X_{\mathrm{j}}$ are the coded experimental levels of the independent variables), respectively.

\section{Results and discussion}

\subsection{Factorial design: removal of 4-AA and TOC abatement}

Table 2 summarizes the observed percentages of degradation and mineralization obtained for the 27 experiments designed according to the levels chosen for the independent variables (Table 1). Predicted responses by CCD for both parameters summarized in Table 2 were generated as arithmetic averages with confidence limits of $\pm 95 \%$, and are shown in Fig. 1a for the percentage of degradation and Fig. 1c for the percentage of mineralization. Correlation coefficients $\left(R^{2}\right)$ and ad-

Table 2

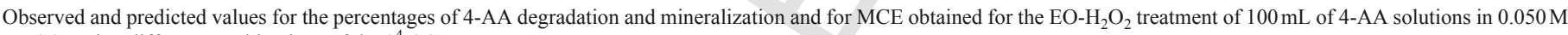
$\mathrm{Na}_{2} \mathrm{SO}_{4}$ using different combinations of the $2^{4} \mathrm{CCD}$.

\begin{tabular}{|c|c|c|c|c|c|c|c|c|c|c|c|}
\hline Experiment & $\begin{array}{l}\text { Current density } \\
\left(\mathrm{mA} \mathrm{cm}^{-2}\right)\end{array}$ & $\mathrm{pH}$ & $\begin{array}{l}{[4-\mathrm{AA}]} \\
\left(\mathrm{mg} \mathrm{L}^{-1}\right)\end{array}$ & $\begin{array}{l}\text { Time for } \\
\text { degradation (min) }\end{array}$ & $\begin{array}{l}\text { Time for mineralization and } \\
\text { for MCE ( } \mathrm{min})\end{array}$ & $\% 4-\mathrm{AA} d$ & egradation & $\begin{array}{l}\% 4-\mathrm{AA} \\
\text { mineraliza }\end{array}$ & tion & MCE (\%) & \\
\hline & & & & & & Observed & Predicted & Observed & Predicted & Observed & Predicted \\
\hline 1 & 32.5 & 3.5 & 62.5 & 3 & 65 & 31 & 27.9 & 8 & 11.5 & 8.0 & 8.6 \\
\hline 2 & 32.5 & 3.5 & 62.5 & 7 & 175 & 64 & 59.5 & 22 & 26.4 & 5.9 & 7.0 \\
\hline 3 & 32.5 & 3.5 & 137.5 & 3 & 65 & 6 & 8.5 & 4 & 6.4 & 5.3 & 5.3 \\
\hline 4 & 32.5 & 3.5 & 137.5 & 7 & 175 & 41 & 36.2 & 16 & 16.5 & 10.0 & 9.7 \\
\hline 5 & 32.5 & 8.5 & 62.5 & 3 & 65 & 14 & 21.0 & 8 & 7.3 & 3.6 & 4.4 \\
\hline 6 & 32.5 & 8.5 & 62.5 & 7 & 175 & 43 & 38.7 & 24 & 24.4 & 2.3 & 1.4 \\
\hline 7 & 32.5 & 8.5 & 137.5 & 3 & 65 & 3 & 2.2 & 4 & 3.4 & 1.2 & 3.7 \\
\hline 8 & 32.5 & 8.5 & 137.5 & 7 & 175 & 13 & 15.9 & 15 & 15.8 & 7.6 & 6.3 \\
\hline 9 & 77.5 & 3.5 & 62.5 & 3 & 65 & 63 & 58.0 & 20 & 21.4 & 1.5 & 3.3 \\
\hline 10 & 77.5 & 3.5 & 62.5 & 7 & 175 & 99 & 95.7 & 45 & 47.5 & 2.1 & 0.3 \\
\hline 11 & 77.5 & 3.5 & 137.5 & 3 & 65 & 34 & 34.2 & 14 & 15.5 & 5.2 & 5.0 \\
\hline 12 & 77.5 & 3.5 & 137.5 & 7 & 175 & 77 & 67.9 & 34 & 36.9 & 6.1 & 5.8 \\
\hline 13 & 77.5 & 8.5 & 62.5 & 3 & 65 & 33 & 33.7 & 16 & 17.4 & 2.9 & 3.9 \\
\hline 14 & 77.5 & 8.5 & 62.5 & 7 & 175 & 62 & 57.4 & 46 & 45.8 & 2.9 & 1.3 \\
\hline 15 & 77.5 & 8.5 & 137.5 & 3 & 65 & 8 & 10.4 & 15 & 12.8 & 6.7 & 6.0 \\
\hline 16 & 77.5 & 8.5 & 137.5 & 7 & 175 & 31 & 30.0 & 38 & 36.4 & 7.2 & 7.3 \\
\hline 17 & 10 & 6.0 & 100 & 5 & 120 & 5 & 4.4 & 12 & 15.9 & 12.4 & 10.4 \\
\hline 18 & 100 & 6.0 & 100 & 5 & 120 & 42 & 45.6 & 40 & 39.0 & 4.0 & 5.7 \\
\hline 19 & 55 & 1.0 & 100 & 5 & 120 & 52 & 58.1 & 25 & 21.7 & 5.1 & 4.4 \\
\hline 20 & 55 & 11.0 & 100 & 5 & 120 & 22 & 19.3 & 9 & 15.7 & 1.7 & 1.9 \\
\hline 21 & 55 & 6.0 & 25 & 5 & 120 & 65 & 66.5 & 37 & 36.8 & 1.7 & 1.9 \\
\hline 22 & 55 & 6.0 & 175 & 5 & 120 & 23 & 25.8 & 18 & 22.4 & 6.2 & 5.4 \\
\hline 23 & 55 & 6.0 & 100 & 1 & 10 & 15 & 10.2 & 4 & 4.5 & 10.6 & 7.1 \\
\hline 24 & 55 & 6.0 & 100 & 9 & 230 & 50 & 58.5 & 44 & 49.7 & 4.8 & 6.4 \\
\hline 25 & 55 & 6.0 & 100 & 5 & 120 & 32 & 30.0 & 28 & 27.6 & 5.4 & 6.3 \\
\hline 26 & 55 & 6.0 & 100 & 5 & 120 & 34 & 30.0 & 26 & 27.6 & 5.1 & 6.3 \\
\hline 27 & 55 & 6.0 & 100 & 5 & 120 & 29 & 30.0 & 26 & 27.6 & 5.1 & 6.3 \\
\hline
\end{tabular}



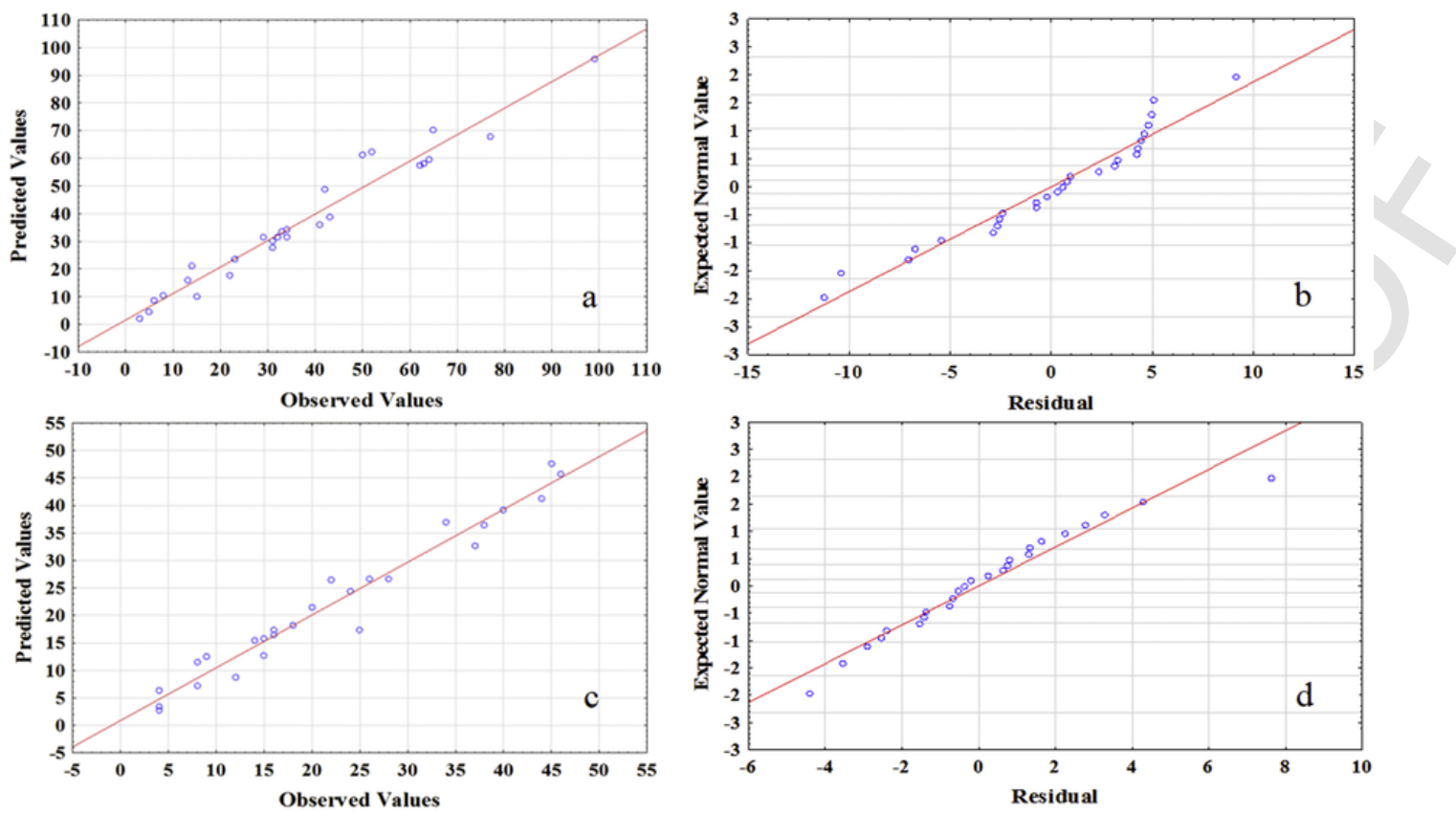

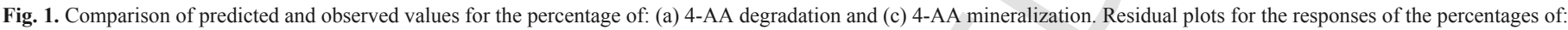
(b) 4-AA degradation and (d) 4-AA mineralization.

justed correlation coefficients $\left(R_{\text {adj }}^{2}\right)$ were determined from the observed and predicted values, respectively. Both sets of values were quite similar, exhibiting a very good linear relationship (see Fig. 1a and c), with $R^{2}=0.956$ and $R_{\text {adj }}^{2}=0.905$ for the percentage of 4-AA degradation and $R^{2}=0.959$ and $R_{\text {adj }}^{2}=0.913$ for the percentage of 4-AA mineralization. Based in the good agreements between the experimental and predicted values, it can be concluded that the model was satisfactory (Kasiri and Khata, 2011; Da Silva et al., 2016).

Fig. $1 \mathrm{~b}$ and $\mathrm{d}$ shows the excellent linear correlations obtained between the corresponding expected normal values and the residuals (i.e., the difference between the predicted and observed values, corresponding to variation elements unexplained by the fitted model). As can be seen, the two mathematical models were robust, yielding close values to the experimental data and thus providing low residual values that are expected to follow a normal distribution, being independent between them (Bezerra et al., 2008; Kasiri and Khata, 2011; Da Silva et al., 2016). Therefore, the proposed models for the observed sets of experimental data were suitable to describe both responses (Savic et al., 2014; Da Silva et al., 2016).

\subsubsection{Percentage of 4-AA degradation}

Fig. 2a shows the Pareto chart for the percentage of degradation, revealing that the four linear independent variables, as well as a quadratic initial drug concentration, were statistically significant with $p<0.05$. Furthermore, the interaction between $j$ and $\mathrm{pH}$ (1Lby2L term) was also significant. Fig. $2 \mathrm{~b}$ exemplifies the response surface generated for the percentage of 4-AA degradation vs. $\mathrm{pH}$ and $j$ treating $62.5 \mathrm{mg} \mathrm{L}^{-1}$ drug for $3 \mathrm{~min}$.

Fig. $2 \mathrm{~b}$ depicts that at $\mathrm{pH} 8.5$, the current density did not exert a great effect on 4-AA degradation, as demonstrated by similar values of drug removal at lower and higher $j$ values. In contrast, at $\mathrm{pH} 3.5$, a gradually higher $j$ caused a larger degradation. For example, $63 \%$ degradation was achieved at $j=77.5 \mathrm{~mA} \mathrm{~cm}^{-2}$, being much $>31 \%$ obtained at $j=32.5 \mathrm{~mA} \mathrm{~cm}^{-2}$. Increasing $j$ usually leads to a higher rate of all electrochemical reactions. This is confirmed for 4-AA at
$\mathrm{pH} 3.5$, producing a faster direct oxidation of the drug at the anode and the production of larger amounts of $\mathrm{BDD}\left({ }^{\circ} \mathrm{OH}\right)$ and $\mathrm{H}_{2} \mathrm{O}_{2}$ via reactions (1) and (2), respectively, thereby enhancing its removal. From Table 2 , it can be seen that $99 \%$ of 4 -AA removal could be attained after only $7 \mathrm{~min}$ at $j=77.5 \mathrm{~mA} \mathrm{~cm}^{-2}$.

It is evident that the treatment at acidic $\mathrm{pH}$ showed a much better performance regarding the 4-AA degradation as compared to that in alkaline medium. To explain this effect, the amount of $\mathrm{H}_{2} \mathrm{O}_{2}$ accumulated in the bulk was determined under the above optimum conditions. About 5.2 and $2.5 \mathrm{mM} \mathrm{H}_{2} \mathrm{O}_{2}$ were found after $7 \mathrm{~min}$ of $\mathrm{EO}-\mathrm{H}_{2} \mathrm{O}_{2}$ treatment of $62.5 \mathrm{mg} \mathrm{L}^{-1}$ drug at $j=77.5 \mathrm{~mA} \mathrm{~cm}^{-2}$ at pH 3.5 and 8.5 , respectively. This behavior suggests a much larger consumption of $\mathrm{H}_{2} \mathrm{O}_{2}$ at $\mathrm{pH}=8.5$, which can be related to fast reactions of $\mathrm{BDD}\left(\mathrm{HO}_{2}{ }^{\circ}\right)$ formed from reaction (3) with oxidation products of 4-AA. These reactions compete with the direct anodic oxidation of the parent pollutant at the anode and its attack by $\operatorname{BDD}\left({ }^{\circ} \mathrm{OH}\right)$, thus decelerating the drug removal.

The signs of the estimated regression coefficients account for the effect of the independent variables on the treatment. Therefore, positive coefficients inform about a larger degradation upon increase of the given variable value within the range tested. Conversely, negative coefficients indicate a better performance when the value of the variable is diminished. The interaction variables $X_{\mathrm{i}} X_{\mathrm{j}}$ cause a synergistic or antagonistic influence if they are accompanied by positive or negative coefficients, respectively (Nogueira et al., 2005; Calza et al., 2013; Da Silva et al., 2016).

The quadratic model generated for the percentage of 4-AA degradation is given by Eq. (6):

$$
\begin{aligned}
Y(\% \text { degr. })= & 31.67+22.17 X_{1}-22.3 X_{2}-23.3 X_{3} \\
& +7.7 X_{3}^{2}+25.67 X_{4}-8.8 X_{1} X_{2}
\end{aligned}
$$

where $X_{\mathrm{i}}$ denote the levels of the independent variables (see subSection 2.4). Apart from the linear variables, Eq. (6) shows that 

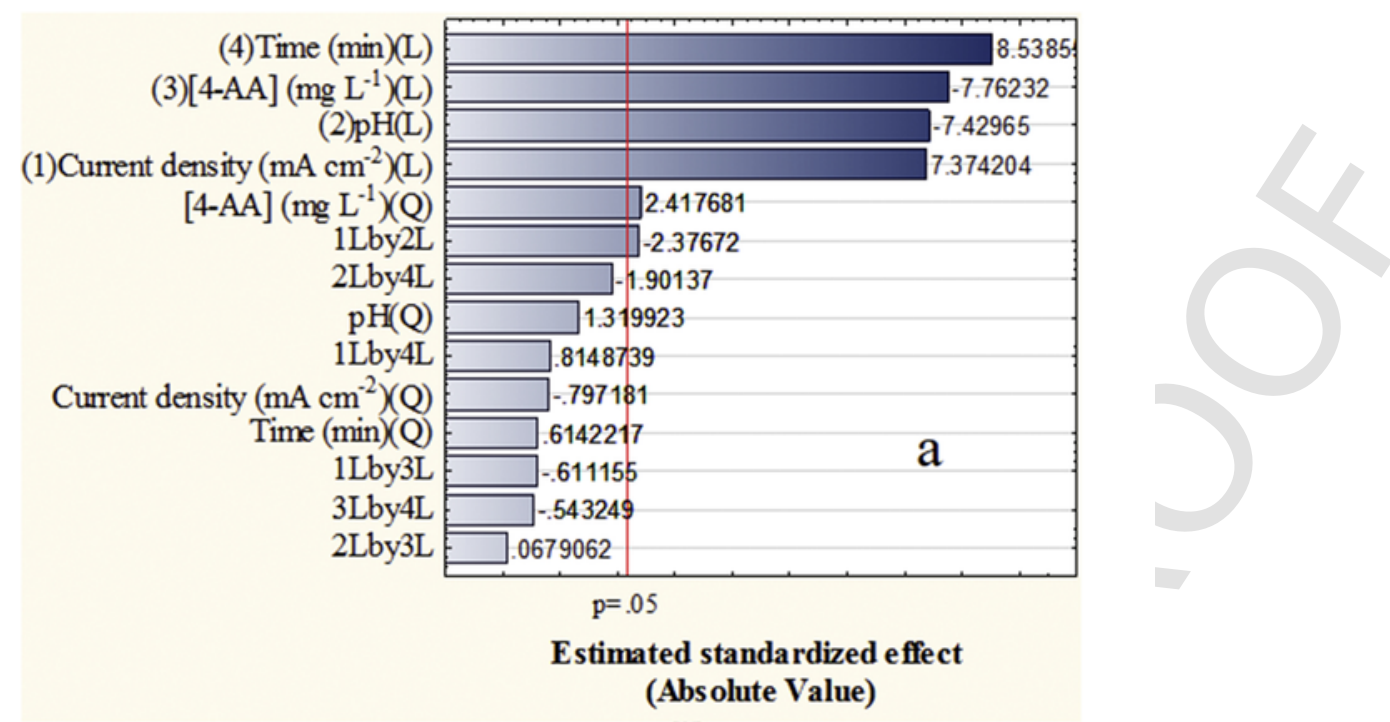

(Abs olute Value)

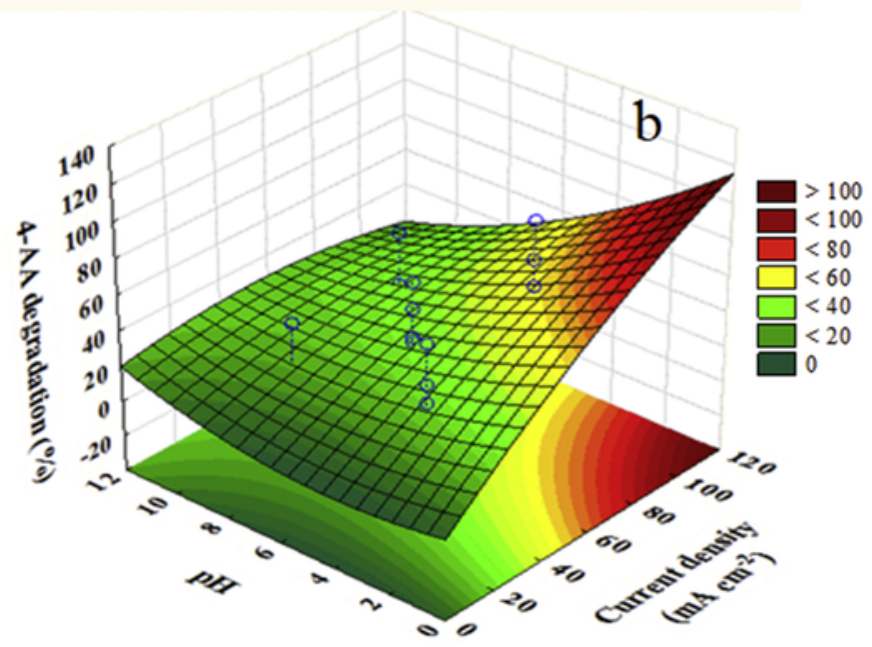

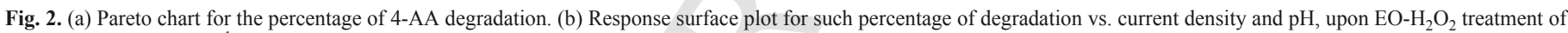
solutions with $62.5 \mathrm{mg} \mathrm{L}^{-1}$ drug for $3 \mathrm{~min}$

the quadratic variable $X_{3}^{2}$ and the interaction $X_{1} X_{2}$ term have an important influence on the response.

Positive coefficients can be observed in Eq. (6) for $j$ and electrolysis time, which reveals an enhancement of the percentage of degradation when these variables adopt higher values. Nevertheless, it must be taken into account that the rise in current is expected to decrease the efficiency of the process due to the acceleration of parasitic reactions of $\mathrm{BDD}(\mathrm{OH})$, causing a larger production of $\mathrm{O}_{2}$ gas as a first collateral effect, along with an enhancement of $\mathrm{H}_{2}$ evolution at the cathode from water reduction (Sirés et al., 2014; Brillas and Sirés, 2015; Benito et al., 2017). The positive influence of electrolysis time is logical since longer time tends to favor the gradual oxidation of drug molecules. The negative coefficient for $\mathrm{pH}$ indicates a quicker degradation as the solution becomes more acid, also associated with the production of more $\mathrm{H}_{2} \mathrm{O}_{2}$, as pointed out above. The fact that 4-AA concentration was accompanied by a negative coefficient in Eq. (6) can be simply associated with the quicker removal of lower amounts of molecules under similar oxidative, since a steady concentration of oxidants can deal better with a limited number of drug molecules present in the medium (Sirés et al., 2014; Brillas and Sirés, 2015). In contrast, the quadratic 4-AA concentration showed a smaller but positive coefficient, as expected if its rise enhanced the degradation efficiency, according to the prediction of a rotatability model (Brereton, 2003; Singh et al., 2004). Note that the negative relationship between $j$ and $\mathrm{pH}\left(X_{1} X_{2}\right.$ term in Eq. (6)) revealed an antagonistic effect on the degradation and then, similar percentages of degradation can be achieved with an opposite change of both variables. For example, after $3 \mathrm{~min}$ of treatment of $62.5 \mathrm{mg} \mathrm{L}^{-1} 4-\mathrm{AA}, 31 \%$ degradation was reached at $j=32.5 \mathrm{~mA} \mathrm{~cm}^{-2}$ and $\mathrm{pH}=3.5$, exhibiting close value at $j=77.5 \mathrm{mAcm}^{-2}$ and $\mathrm{pH}=8.5$ with $33 \% 4$-AA degradation. Consequently, the interaction effects between the independent variables are of extreme importance to predict the observed percentages of 4-AA degradation using CCD.

\subsubsection{Percentage of 4-AA mineralization}

The Pareto chart of Fig. 3a evidences the statistical significance $(p<0.05)$ of $j$, initial drug concentration, electrolysis time, quadratic variable $\mathrm{pH}$ and the relationship between $j$ and time (1Lby4L term) to describe the behavior of the percentage of 4-AA mineralization. The response surface of this latter parameter against $j$ and time for EO- $\mathrm{H}_{2} \mathrm{O}_{2}$ treatments of $62.5 \mathrm{mg} \mathrm{L}^{-1} 4-\mathrm{AA}$ at $\mathrm{pH}=3.5$ is presented in Fig. $3 \mathrm{~b}$. No significant influence of $\mathrm{pH}$ on the mineralization rates was found, in agreement with similar treatments of other organics (Moreira et al., 2017). It is worth remarking that high $j$ values and 


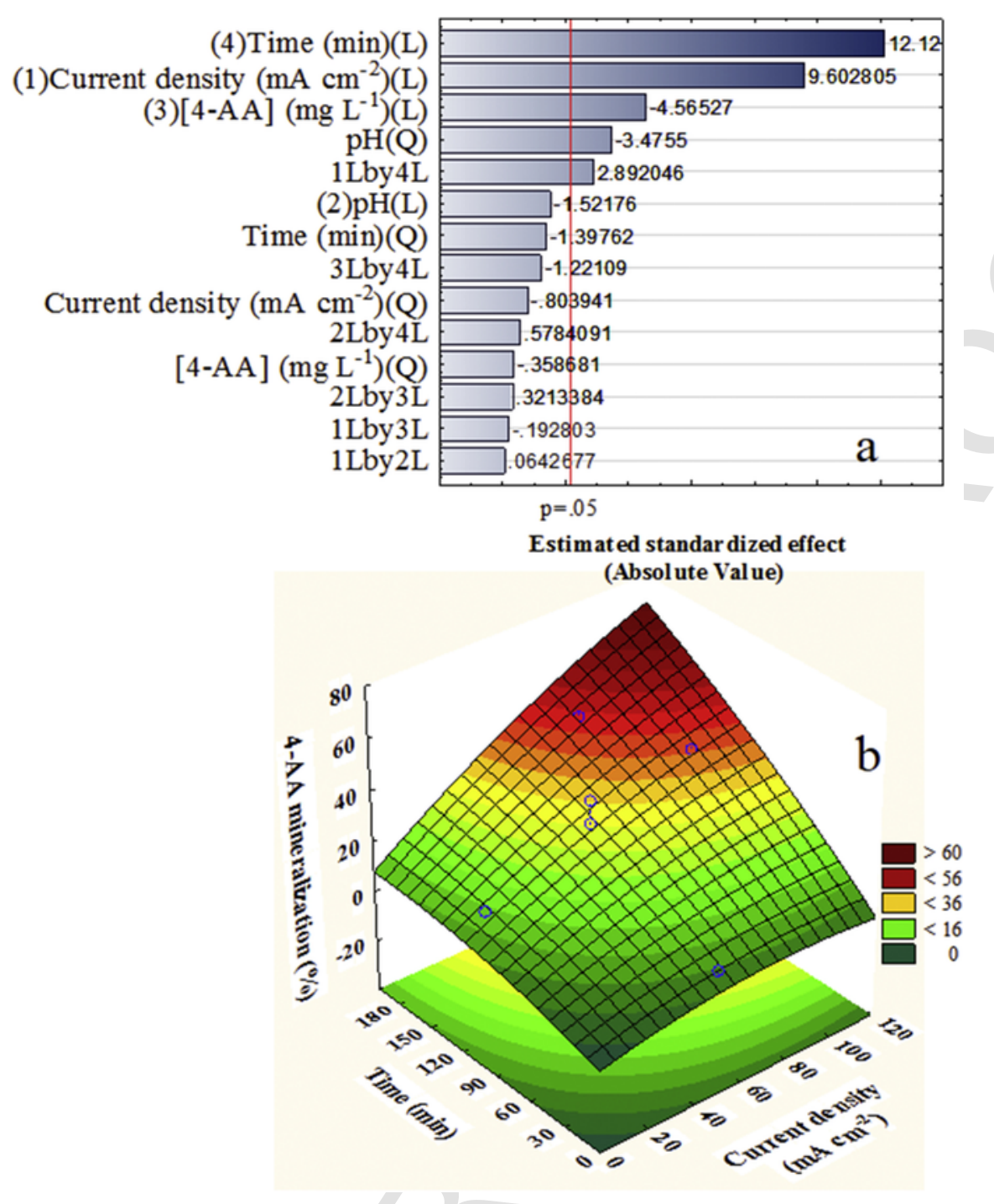

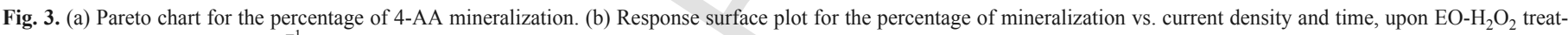
ment of solutions with $62.5 \mathrm{mg} \mathrm{L}^{-1}$ drug at $\mathrm{pH}=3.5$.

long times were required to attain a relatively large mineralization. For example, under the optimum conditions found above for the 4-AA degradation $\left(j=77.5 \mathrm{mAcm}^{-2}, \mathrm{pH}=3.5\right.$ and $62.5 \mathrm{mgL}^{-1}$ drug), only $45 \%$ mineralization was reached after $175 \mathrm{~min}$. Prolonging the treatment until $510 \mathrm{~min}$, an almost total mineralization with $91 \%$ TOC abatement was already achieved, indicating that ROS (mainly $\mathrm{BDD}(\mathrm{OH}))$ originated in the $\mathrm{EO}-\mathrm{H}_{2} \mathrm{O}_{2}$ process are able to destroy most of the products formed from 4-AA oxidation (Rabaaoui et al., 2013; Moreira et al., 2017).

The estimated regression coefficients allowed generating the following empirical model as response for the percentage of 4-AA mineralization:

$$
\begin{aligned}
Y(\% \text { miner })= & 26.67+15.25 X_{1}-7.25 X_{3} \\
& +19.25 X_{4}-5.85 X_{2}^{2}+5.63 X_{1} X_{4}
\end{aligned}
$$

where $X_{\mathrm{i}}$ correspond to the same variables cited above, and $X_{1} X_{4}$ represents the interaction term between $j$ and time.
The positive coefficients of $j$ and time in Eq. (7) represent an improvement of mineralization with the increase of their values. The small positive coefficient for the relationship between $j$ and time $\left(X_{1} X_{4}\right.$ term) highlights a synergistic effect since a simultaneous increase of their values enhances the TOC removal. This can be deduced from the behavior found for $62.5 \mathrm{mg} \mathrm{L}^{-1}$ drug at $\mathrm{pH}=3.5$, where TOC was reduced by $8 \%$ and $22 \%$ after 65 and $175 \mathrm{~min}$ at $j=32.5 \mathrm{~mA} \mathrm{~cm}^{-2}$, respectively, whereas it increased to $45 \%$ after $175 \mathrm{~min}$ at $j=77.5 \mathrm{~mA} \mathrm{~cm}^{-2}$. On the other hand, the 4-AA concentration exhibited a negative coefficient, as expected if the mineralization was favored at lower drug content owing to the smaller amount of organic matter to be mineralized with the steady concentration of oxidants (Sirés et al., 2014; Brillas and Sirés, 2015).

The quadratic variable $\mathrm{pH}$ exhibited a negative coefficient. Thus, in this model the quadratic variable can be reduced, demonstrating still efficiency in the prediction for the model based on rotatability (Brereton, 2003; Singh et al., 2004). 


\subsubsection{Mineralization current efficiency}

The inorganic nitrogenated ions released from the $\mathrm{N}$ atoms $(0.732 \mathrm{mM})$ present in a $50 \mathrm{mgL}^{-1}$ 4-AA solution with $0.050 \mathrm{M}$ $\mathrm{Na}_{2} \mathrm{SO}_{4}$ at $\mathrm{pH}=3$ upon EO- $\mathrm{H}_{2} \mathrm{O}_{2}$ treatment were analyzed after $210 \mathrm{~min}$ of electrolysis at $j=80 \mathrm{~mA} \mathrm{~cm}^{-2}$. Concentrations of $0.26 \mathrm{mM}$ of $\mathrm{NO}_{3}{ }^{-}$ion $(8.0 \%$ of initial $\mathrm{N})$ and $0.82 \mathrm{mM}$ of $\mathrm{NH}_{4}{ }^{+}$ion $(87.1 \%$ of initial $\mathrm{N}$ ) were obtained. These results revealed the mineralization of $95.1 \%$ of initial $\mathrm{N}$, suggesting that the rest of $\mathrm{N}$ either remained in the final solution as $\mathrm{N}$-derivatives or was partly lost as volatile species such as $\mathrm{N}_{2}$ and $\mathrm{N}_{\mathrm{x}} \mathrm{O}_{\mathrm{y}}$ (Sirés et al., 2014; Moreira et al., 2017). From these findings, the following theoretical reaction can be proposed for 4-AA mineralization with formation of $\mathrm{NH}_{4}{ }^{+}$as pre-eminent ion and a number of electrons $(n)$ equal to 46 :

$$
\begin{aligned}
\mathrm{C}_{11} \mathrm{H}_{13} \mathrm{~N}_{3} \mathrm{O}+21 \mathrm{H}_{2} \mathrm{O} \rightarrow & 11 \mathrm{CO}_{2}+3 \mathrm{NH}_{4}^{+} \\
+ & 43 \mathrm{H}^{+}+46 \mathrm{e}^{-}
\end{aligned}
$$

Considering $\Delta(\mathrm{TOC})_{\exp }$ as the decay in experimental TOC (in $\mathrm{mg} \mathrm{L}^{-1}$ ) obtained for the different assays, the dependent variable MCE was calculated at each current $I$ (in A) and electrolysis time $t$ (in h) as follows (Sirés et al., 2014; Steter et al., 2016):
$\operatorname{MCE}(\%)=\frac{n F V_{s} \Delta(\mathrm{TOC})_{\exp }}{4.32 \times 10^{7} m I t} 100$

where $F$ is the Faraday constant, $\mathrm{V}_{\mathrm{s}}$ is the solution volume (in L), $4.32 \times 10^{7}$ is a factor to homogenize units and $m=11$ is the number of carbon atoms of $4-\mathrm{AA}$.

The MCE values determined from Eq. (9) and listed in Table 2 were small $(\leq 12.4 \%)$, as a result of the large recalcitrance of intermediates generated. Fig. 4 a presents the Pareto chart related to MCE, showing that only $j$, initial [4-AA] and the relationship between $j$ and $\mathrm{pH}(1 \mathrm{Lby} 2 \mathrm{~L}$ term) were statistically significant $(p<0.05)$. The response surface plot for this parameter against $j$ and $\mathrm{pH}$ for the treatment of $62.5 \mathrm{mg} \mathrm{L}^{-1}$ drug for $65 \mathrm{~min}$ is shown in Fig. 4b. It should be noted that Eq. (9) reveals that $I$ (or $j$ ) and time are inversely proportional to $\mathrm{MCE}$ and hence, their increase causes a decrease of this parameter. In contrast, MCE depends directly on $\triangle(T O C)_{\exp }$ at any given electrolysis time. Optimum mineralization conditions were found at a low $j=32.5 \mathrm{~mA} \mathrm{~cm}^{-2}$, with MCE values of $8 \%$ at $\mathrm{pH}=3.5$ and $3.6 \%$ at $\mathrm{pH}=8.5$ after $65 \mathrm{~min}$ of treatment. At the same electrolysis time, a higher $j=77.5 \mathrm{~mA} \mathrm{~cm}^{-2}$ yielded lower MCE values of $1.5 \%$ and $2.9 \%$.

Eq. (10) gives the quadratic model generated by CCD for MCE as a function of the levels of $X_{1}$ and $X_{3}$ related to the variables $j$ and initial 4-AA concentration, respectively:

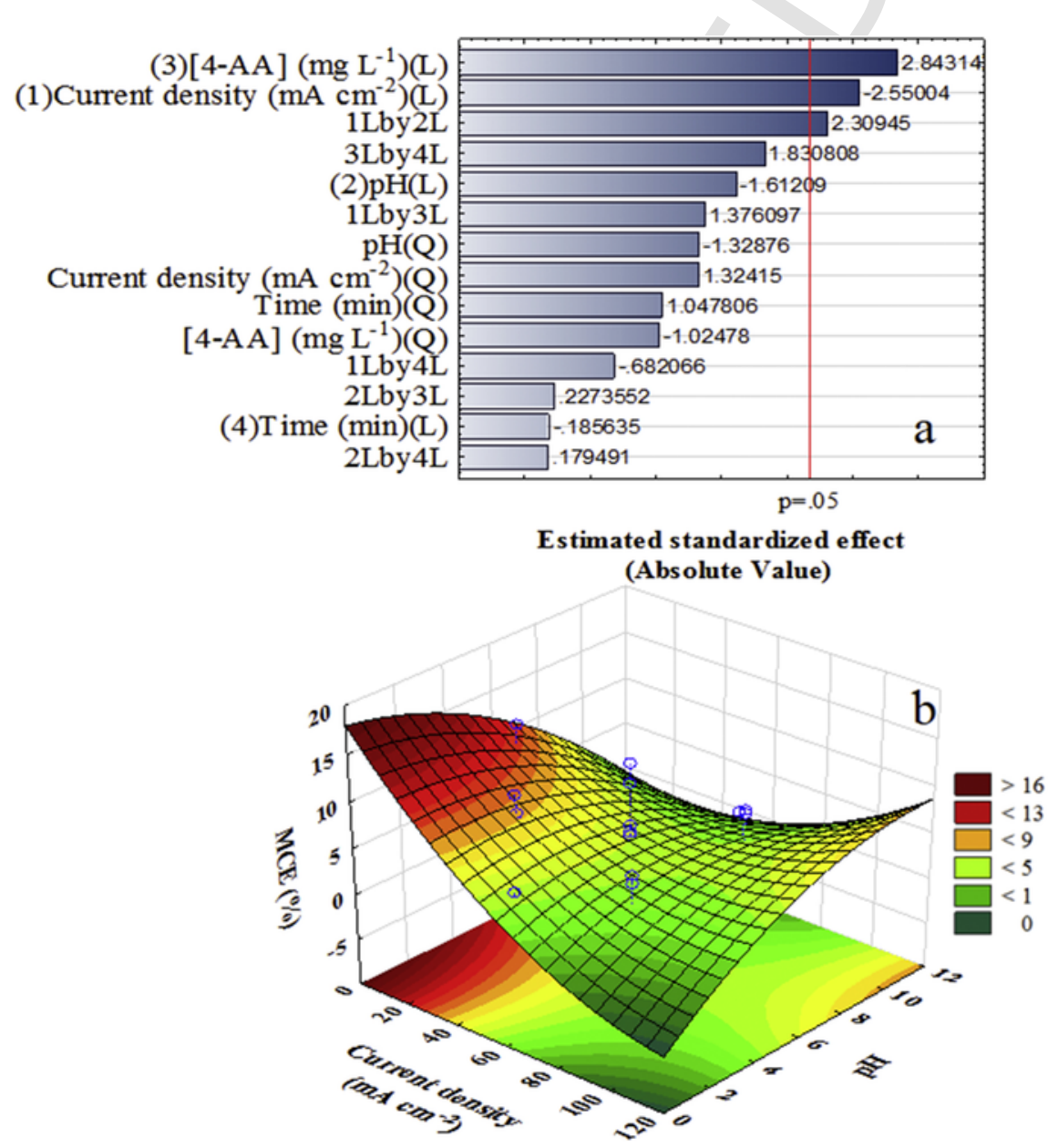

Fig. 4. (a) Pareto chart for MCE and (b) response surface plot of MCE vs. current density and $\mathrm{pH}$, upon $\mathrm{EO}-\mathrm{H}_{2} \mathrm{O}_{2}$ treatment of solutions with $62.5 \mathrm{mg} \mathrm{L} \mathrm{L}^{-1}$ drug for $65 \mathrm{~min}$. 


$$
Y(\mathrm{MCE})=5.2-2.18 X_{1}+2.43 X_{3}+2.41 X_{1} X_{2}
$$

where $X_{1} X_{2}$ denotes the interaction term between $j$ and $\mathrm{pH}$.

The negative coefficient of $j$ predicts that its rise causes a decay of MCE, whereas the positive coefficient of [4-AA] is related to an enhancement of MCE at higher organic matter content owing to the direct relationship of this response with $\Delta(\mathrm{TOC})_{\exp }$. The synergistic effect of the interaction between $j$ and $\mathrm{pH}$ presupposes that the simultaneous decrease of both variables yields the same effect over MCE. For example, for $62.5 \mathrm{mg} \mathrm{L}^{-1} 4$-AA solutions treated for $65 \mathrm{~min}$ gave $2.9 \% \mathrm{MCE}$ at $j=77.5 \mathrm{~mA} \mathrm{~cm}^{-2}$ and $\mathrm{pH} 8.5$, which increased to $8 \%$ MCE by decreasing $j$ to $32.5 \mathrm{~mA} \mathrm{~cm}^{-2}$ and $\mathrm{pH}$ to 3.5 , attaining close $\Delta(\text { TOC })_{\exp }$ values of 8 and $9 \mathrm{mgL}^{-1}$, respectively. This confirms that the mineralization current efficiency of the process is strongly related to the applied $j$ value.

\subsection{Detection of primary intermediates and proposed initial reaction pathway}

The primary oxidation products of 4-AA (1) were determined by LC-MS analysis of the final solutions obtained upon EO- $\mathrm{H}_{2} \mathrm{O}_{2}$ treatment of a $62.5 \mathrm{mg} \mathrm{L}^{-1}$ drug solution in $0.050 \mathrm{M} \mathrm{Na}_{2} \mathrm{SO}_{4}$ at $\mathrm{pH}=3.5$ and $j=77.5 \mathrm{~mA} \mathrm{~cm}^{-2}$, after 3 and $7 \mathrm{~min}$ of electrolysis Molecular peaks of $11[\mathrm{M}+\mathrm{H}]^{+}$species with $\mathrm{m} / \mathrm{z}$ values ranging between 164 and 272 were identified, along with one peak of $\mathrm{m} / \mathrm{z} 440$ corresponding to a dimer derivative. The major part of these primary products were hydroxylated and carboxylic acid derivatives arising from the attack of $\mathrm{BDD}\left({ }^{\circ} \mathrm{OH}\right)$ onto the pyrazolone ring of 4 -AA. From these findings, Fig. 5 shows a proposed reaction pathway for the initial<smiles>CC(=O)N(C)C(C)=O</smiles><smiles>[13CH3]</smiles>

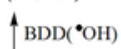

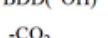<smiles>CC(=O)N(C(=O)O)N(C)c1ccccc1</smiles>

$9(m / z 208)$<smiles></smiles><smiles>CC(=O)N(C)N(C(=O)O)c1cccc(O)c1</smiles>

$(\mathrm{HO})_{3}$

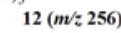<smiles>[10BH2][18OH]</smiles>

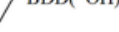<smiles>CC(=O)N(C)N(C(=O)O)/C(C=C(O)CO)=C/CO</smiles>

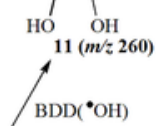<smiles>CC(=O)N(C)N(C(=O)C(=O)O)c1ccccc1</smiles>

$8(m / z 236)$<smiles>C1[13CH][13CH]2C[C@@H]12</smiles><smiles>C1=CC=CCCCC=CC=C1</smiles><smiles>CCOCCOC(=O)c1ccccc1</smiles>

$6(m / 220)$

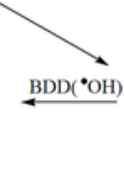

$\mathrm{DD}\left(0^{\circ} \mathrm{OH}\right)$<smiles>CC(=O)N(C)N(C(N)=O)c1ccccc1</smiles>

$4(m / 235)$<smiles>CC(C)[18OH]</smiles><smiles>CNN(C(=O)C(N)=O)c1ccccc1</smiles><smiles>CNN(C(=O)C(=O)O)c1ccccc1</smiles>

Fig. 5. Proposed reaction pathway for the initial degradation of 4-AA by $\mathrm{EO}-\mathrm{H}_{2} \mathrm{O}_{2}$ treatment at $\mathrm{pH}=3.5$. 
degradation of 4-AA by this electrochemical AOP where the above radical was assumed as the main oxidant, although slower parallel oxidation with other ROS (e.g., $\mathrm{H}_{2} \mathrm{O}_{2}$ and $\mathrm{HO}_{2}{ }^{\circ}$ ) is feasible as well. Note that the compounds with $\mathrm{m} / \mathrm{z} 164,220,235,236$ and 260 have been previously reported using photodegradation, ozonation, Fenton and photo-Fenton for 4-AA treatment (Pérez-Estrada et al., 2007; Gómez et al., 2008; Giri and Golder, 2015; Miao et al., 2015a, 2015b).

The route is initiated by the hydroxylation of $1(\mathrm{~m} / \mathrm{z} 203)$ with the cleavage of the $\mathrm{C}(3)-\mathrm{C}(4)$ bond of the pyrazolone ring to yield $\mathbf{2}(\mathrm{m} / \mathrm{z}$ 239). This compound undergoes either dimerization with $\mathbf{1}$ to form $\mathbf{3}$ $(\mathrm{m} / \mathrm{z} 440)$ or oxidation to derivative $4(\mathrm{~m} / \mathrm{z} 235)$ that contains three carbonyl groups due to the simultaneous transformation of the alcohol groups of 2. Fig. 6 schematizes the mechanism proposed for the generation of dimer 3 , involving the oxidation of the $-\mathrm{NH}_{2}$ group of the pyrazolone ring of $\mathbf{1}$ by direct charge transfer to the BDD anode to give its radical cation $\mathbf{1}^{+\bullet}$ (Hu et al., 2010; Benito et al., 2017). Note that this kind of radical cation may also be formed upon action of $\mathrm{BDD}\left({ }^{\circ} \mathrm{OH}\right)$, as was proposed to explain the demethylation of 4 -( $N, N$-dimethyl)-aminoantipyrine (Santos et al., 2010). This radical then attacks the $\mathrm{C}(4)$ of the benzene ring of 2 via $\mathrm{BDD}\left({ }^{\circ} \mathrm{OH}\right)$ oxidation with deprotonation and water formation to form the dimer 3. Fig. 5 also shows that subsequent deacetylation or deamination of the amide group of 4 leads to the formation of $5(\mathrm{~m} / \mathrm{z} 193)$ or $\mathbf{6}(\mathrm{m} / \mathrm{z} 220)$, respectively. Compound $\mathbf{5}$ then undergoes deamination due to hydroxylation, with formation of the carboxylic acid 7 ( $\mathrm{m} / \mathrm{z} 194)$, whereas compound $\mathbf{6}$ is consecutively oxidized to originate the carboxylic acid product $8(\mathrm{~m} / \mathrm{z} 236)$ and decarboxylated to yield $\mathbf{9}(\mathrm{m} / \mathrm{z} 208)$. Finally, compound 9 is further decarboxylated to $\mathbf{1 0}(\mathrm{m} / \mathrm{z} 164)$, undergoes a multiple hydroxylation with cleavage of the benzenic ring to form the aliphatic carboxylic acid $11(\mathrm{~m} / \mathrm{z} 260)$, or the benzene moiety is trihydroxylated to $\mathbf{1 2}(\mathrm{m} / \mathrm{z} 256)$, which is subsequently hydroxylated to $\mathbf{1 3}$ $(\mathrm{m} / \mathrm{z} 272)$. Note that hydroxylation of the aromatic ring has also been found to be a main degradation route in the case of other aminoantipyirines (Santos et al., 2010).

The mineralization process followed by the primary products is much longer than 4-AA removal because many intermediates react very slowly with $\operatorname{BDD}\left({ }^{\circ} \mathrm{OH}\right)$, such as the final short-chain aliphatic carboxylic acids expected to be formed from the breaking of the benzene ring of the molecule upon hydroxylation (Feng et al., 2013; Sirés et al., 2014; Moreira et al., 2017). This is supported by the fact that up to $510 \mathrm{~min}$ were required to reach $91 \%$ mineralization of the
$62.5 \mathrm{mgL}^{-1}$ solution at $\mathrm{pH}=3.5$ and $j=77.5 \mathrm{mAcm}^{-2}$, a time much longer than $7 \mathrm{~min}$ needed to remove the parent drug.

\subsection{Acute toxicity to Artemia salina}

The assessment of the toxicity of by-products generated by AOPs compared to the initial organic pollutants is crucial, aiming to shorten the duration of expensive treatment and combine them with low cost processes. To do this, the larvae of microcrustacean Artemia salina have been widely used because they are easy to handle and show an acute toxicity response to persistent pollutants (Marković et al., 2015; Da Silva et al., 2016). This organism was then employed to evaluate the toxicity of the initial $62.5 \mathrm{mg} \mathrm{L}^{-1} 4-\mathrm{AA}$ solution at $\mathrm{pH}=3.5$, as well as that of the solutions treated for 3 and $7 \mathrm{~min}$ by $\mathrm{EO}-\mathrm{H}_{2} \mathrm{O}_{2}$ at $j=77.5 \mathrm{~mA} \mathrm{~cm}^{-2}$, where $63 \%$ and $99 \%$ of 4 -AA degradation were achieved, respectively. The residual $\mathrm{H}_{2} \mathrm{O}_{2}$ was removed by adding $1 \mathrm{~g} \mathrm{~L}^{-1}$ catalase solution dropwise.

Fig. 7 highlights the variation of the larvae mortality with the concentration of diluted samples prepared with each of the three tested solutions, as described in subSection 2.3. A greater mortality with increasing 4-AA concentration was found for the parent solution, which allowed determining a $\mathrm{LC}_{50}$ value of $13.6 \mathrm{mg} \mathrm{L}^{-1}$. This corresponds to 7.4 acute toxicity units $\left(\mathrm{TU}_{\mathrm{a}}=\left(1 / \mathrm{LC}_{50}\right) \times 100\right)$, which is within the range of 1-10 that informs about a highly toxic chemical (Persoone et al., 2003). In contrast, the solutions treated by EO- $\mathrm{H}_{2} \mathrm{O}_{2}$ did not show any remarkable acute toxicity since larvae mortality was similar to that found for control samples, thus preventing the determination of their $\mathrm{LC}_{50}$ values (Persoone et al., 2003). These findings reveal the non-toxic nature of hydroxylated and carboxylic acids products formed from this treatment (see Section 3.2), in agreement with results reported for the degradation of other drugs (Cavalcante et al., 2015; Marković et al., 2015; Tay and Madehi, 2015; Da Silva et al., 2016).

\section{Conclusions}

It has been shown that a $2^{4} \mathrm{CCD}$ is able to correctly assess the effect of the main independent variables on the $\mathrm{EO}-\mathrm{H}_{2} \mathrm{O}_{2}$ treatment of 4-AA solutions with a stirred BDD/air-diffusion cell. Current density, 4-AA concentration and electrolysis time had an important role regarding the percentages of degradation and mineralization and the $\mathrm{MCE}$. In contrast, the solution $\mathrm{pH}$ did not show significant influence<smiles>CC1C(N)C(=O)N(c2ccccc2)N1C</smiles>

$1(\mathrm{~m} / \mathrm{z} 203)$

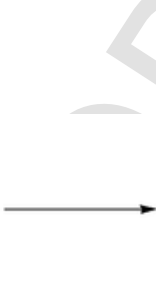

(m/z 239)<smiles>CC1C([NH3+])C(=O)N(c2ccccc2)N1C</smiles>

$1^{+\bullet}$

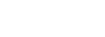<smiles>CC1C([NH3+])C(=O)N(c2ccccc2)N1C</smiles>

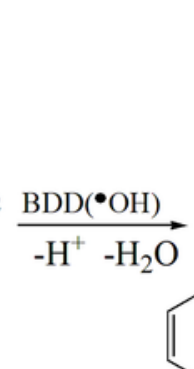<smiles>CC(C)Nc1ccc(N(C(=O)C(N)O)N(C)C(C)O)cc1</smiles> 


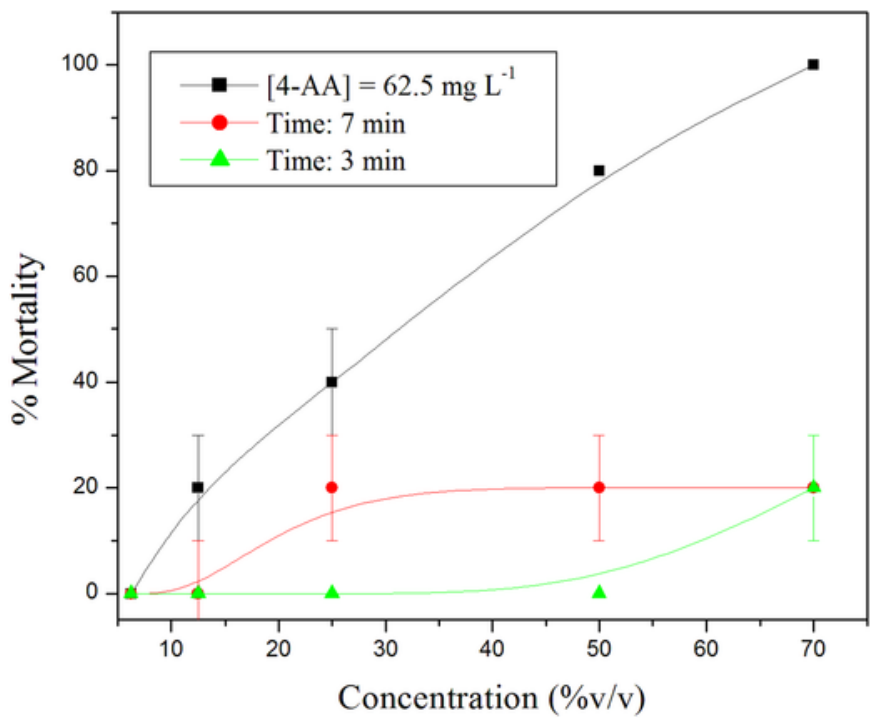

Fig. 7. Change of Artemia salina mortality with the concentration of diluted aliquots of the initial $62.5 \mathrm{mg} \mathrm{L}^{-1} 4-\mathrm{AA}$ solution at $\mathrm{pH}=3.5$ and the remaining solutions after EO- $\mathrm{H}_{2} \mathrm{O}_{2}$ treatment at $j=77.5 \mathrm{~mA} \mathrm{~cm}^{-2}$ for 3 and $7 \mathrm{~min}$.

on the percentage of mineralization and MCE. Optimum degradation conditions were obtained for $62.5 \mathrm{mg} \mathrm{L}^{-1}$ drug solutions at $\mathrm{pH}=3.5$ and $j=77.5 \mathrm{~mA} \mathrm{~cm}^{-2}$, where $63 \%$ and $99 \%$ reduction were attained at 3 and $7 \mathrm{~min}$, respectively. For the same kind of solutions, mineralization was optimum at $j=77.5 \mathrm{~mA} \mathrm{~cm}^{-2}$, with $45 \%$ TOC abatement in $175 \mathrm{~min}$. Operating at $j=77.5 \mathrm{~mA} \mathrm{~cm}^{-2}$, an almost total mineralization with $91 \%$ TOC decay was found after $510 \mathrm{~min}$. A complete initial reaction pathway for 4-AA degradation has been proposed, involving hydroxylated and carboxylic acid derivatives and one dimer. The treated solutions did not cause acute toxicity on Artemia salina, in contrast to parent 4-AA solutions. From these results, EO- $\mathrm{H}_{2} \mathrm{O}_{2}$ with a BDD/air-diffusion cell can be proposed as an effective treatment of wastewater containing this class of drugs.

\section{Acknowledgements}

The authors are grateful to Brazilian funding agencies: Conselho Nacional de Desenvolvimento Científico e Tecnológico (CNPq), Coordenação de Aperfeiçoamento de Pessoal de Nível Superior (Capes) and Fundação de Apoio ao Desenvolvimento do Ensino, Ciência e Tecnologia do Estado de Mato Grosso do Sul (Fundect). Support from Laboratório de Produtos Naturais e Espectrometria de Massas LAPNEM is also acknowledged. We also thank funding from project CTQ2016-78616-R (AEI/FEDER, EU).

\section{References}

APHA, 2012. Standard Methods for the Examination of Water and Wastewater, 22nd ed.American Public Health Association, New York.

Benito, A., Penadés, A., Lliberia, J.L., Gonzalez-Olmos, R., 2017. Degradation pathways of aniline in aqueous solutions during electro-oxidation with BDD electrodes and $\mathrm{UV} / \mathrm{H}_{2} \mathrm{O}_{2}$ treatment. Chemosphere 166, 230-237.

Bezerra, M.A., Santelli, R.E., Oliveira, E.P., Villar, L.S., Escaleira, L.A., 2008. Response surface methodology (RSM) as a tool for optimization in analytical chemistry. Talanta $76,965-977$.

Boye, B., Michaud, P.A., Marselli, B., Dieng, M.M., Brillas, E., Comninellis, C., 2002. Anodic oxidation of 4-chlorophenoxyacetic acid on synthetic boron-doped diamond electrode. New Diamond Front. Carbon Technol. 12, 63-72.

Brereton, R.G., 2003. Chemometrics: Data Analysis for the Laboratory and Chemical Plant. Wiley, Chichester.
Brillas, E., Sirés, I., 2015. Electrochemical removal of pharmaceuticals from water streams: reactivity elucidation by mass spectrometry. TrAC Trends Anal. Chem. $70,112-121$.

Calza, P., Sakkas, V.A., Medana, C.A.D., Vlachou, A.D., Dal Bello, F., Albanis, T.A., 2013. Chemometric assessment and investigation of mechanism involved in photo-Fenton and $\mathrm{TiO}_{2}$ photocatalytic degradation of the artificial sweetener sucralose in aqueous media. Appl. Catal. B Environ. 129, 71-79.

Campos-Mañas, M.C., Plaza-Bolaños, P., Sánchez-Pérez, J.A., Malato, S., Agüera, A., 2017. Fast determination of pesticides and other contaminants of emerging concern in treated wastewater using direct injection coupled to highly sensitive ultra-high performance liquid chromatography-tandem mass spectrometry. J. Chromatogr. A 1507, 84-94.

Cavalcante, R.P., Dantas, R.F., Wender, H., Bayarri, B., Gonzalez, O., Gimenez, J., Esplugas, S., Machulek, A.J., 2015. Photocatalytic treatment of metoprolol with $\mathrm{B}$-doped $\mathrm{TiO}_{2}$ : effect of water matrix, toxicological evaluation and identification of intermediates. Appl. Catal. B Environ. 176-177, 173-182.

Cavalcante, R.P., Dantas, R.F., Bayarri, B., Gonzalez, O., Giménez, J., Esplugas, S., Machulek, A.J., 2016. Photocatalytic mechanism of metoprolol oxidation by photocatalysts $\mathrm{TiO}_{2}$ and $\mathrm{TiO}_{2}$ doped with $5 \% \mathrm{~B}$ : primary active species and intermediates. Appl. Catal. B Environ. 194, 111-122.

Coria, G., Sirés, I., Brillas, E., Nava, J.L., 2016. Influence of the anode material on the degradation of naproxen by Fenton-based electrochemical processes. Chem. Eng. J. 304, 817-825.

Da Silva, L.M., Cavalcante, R.P., Cunha, R.F., Gozzi, F., Dantas, R.F., Oliveira, S.C., Machulek, A.Jr, 2016. Tolfenamic acid degradation by direct photolysis and the UV-ABC/ $\mathrm{H}_{2} \mathrm{O}_{2}$ process: factorial design, kinetics, identification of intermediates, and toxicity evaluation. Sci. Total Environ. 573, 518-531.

Ebele, A.J., Abou-Elwafa Abdallah, M., Harrad, S., 2017. Pharmaceuticals and personal care products (PPCPs) in the freshwater aquatic environment. Emerg. Contam. 3, 1-16.

El Fels, L., Hafidi, M., Ouhdouch, Y., 2016. Artemia salina as a new index for assessment of acute cytotoxicity during co-composting of sewage sludge and lignocellulose waste. Waste Manag. 50, 194-200.

Feng, L., Van Hullebusch, E.D., Rodrigo, M.A., Esposito, G., Oturan, M.A., 2013. Removal of residual anti-inflammatory and analgesic pharmaceuticals from aqueous systems by electrochemical advanced oxidation processes. A review. Chem. Eng. J. 228, 944-964.

Giri, A.S., Golder, A.K., 2015. Decomposition of drug mixture in Fenton and photo-Fenton processes: comparison to singly treatment, evolution of inorganic ions and toxicity assay. Chemosphere 127, 254-261.

Gligorovski, S., Strekowski, R., Barbati, S., Vione, D., 2015. Environmental implications of hydroxyl radicals ('OH). Chem. Rev. 115, 13051-13092.

Gómez, M.J., Sirtori, C., Mezcua, M., Fernández-Alba, A.R., Agüera, A., 2008. Photodegradation study of three dipyrone metabolites in various water systems: identification and toxicity of their photodegradation products. Water Res. 42 , 2698-2706.

Gowda, J.I., Buddanavar, A.T., Nandibewoor, S.T., 2015. Fabrication of multiwalled carbon nanotube-surfactant modified sensor for the direct determination of toxic drug 4-aminoantipyrine. J. Pharm. Anal. 5, 231-238.

Guelfi, D.R.V., Gozzi, F., Sirés, I., Brillas, E., Machulek Jr, A., de Oliveira, S.C., 2017. Degradation of the insecticide propoxur by electrochemical advanced oxidation processes using a boron-doped diamond/air-diffusion cell. Environ. Sci. Pollut. Res. 24, 6083-6095.

Guinea, E., Brillas, E., Centellas, F., Cañizares, P., Rodrigo, M.A., Sáez, C., 2009. Oxidation of enrofloxacin with conductive-diamond electrochemical oxidation, ozonation and Fenton oxidation. A comparison. Water Res. 43, 2131-2138.

$\mathrm{Hu}$, X., Yang, J., Yang, C., Zhang, J., 2010. UV/ $\mathrm{H}_{2} \mathrm{O}_{2}$ degradation of 4-aminoantipyrine: a voltammetric study. Chem. Eng. J. 161, 68-72.

Kasiri, M.B., Khata, A.R., 2011. Photooxidative decolorization of two organic dyes with different chemical structures by $\mathrm{UV} / \mathrm{H}_{2} \mathrm{O}_{2}$ process: experimental design. Desalination 270, 151-159.

Lanzalaco, S., Sirés, I., Sabatino, M.A., Dispenza, C., Scialdone, O., Galia, A., 2017. Synthesis of polymer nanogels by electro-Fenton process: investigation of the effect of main operation parameters. Electrochim. Acta 246, 812-822.

Li, D., Tong, H.-X., Zhang, L., 2013. Preparation of $\mathrm{TiO}_{2} / \mathrm{ITO}$ film by liquid phase deposition and its photoelectrocatalytic activity for degradation of 4-aminoantipyrine. Trans. Nonferrous Metals Soc. China 23, 3306-3311.

Marković, M., Jović, M., Stanković, D., Kovačević, V., Roglić, G., Gojgić-Cvijović, G., Manojlović, D., 2015. Application of non-thermal plasma reactor and Fenton reaction for degradation of ibuprofen. Sci. Total Environ. 505, 1148-1155.

Marselli, B., Garcia-Gomez, J., Michaud, P.A., Rodrigo, M.A., Comninellis, C., 2003. Electrogeneration of hydroxyl radicals on boron-doped diamond electrodes. J. Electrochem. Soc. 150, D79-D83.

Miao, H.-F., Zhu, X.-W., Xu, D.-Y., Lu, M.-F., Huang, Z.-X., Ren, H.-Y., Ruan, W.-Q., 2015. Transformation of aminopyrine during ozonation: characteristics and pathways. Chem. Eng. J. 279, 156-165.

Miao, H.-F., Cao, M., Xu, D.-Y., Ren, H.-Y., Zhao, M.-X., Huang, Z.-X., Ruan, W.-Q., 2015. Degradation of phenazone in aqueous solution with ozone: influencing factors and degradation pathways. Chemosphere 119, 326-333. 
Moreira, F.C., Garcia-Segura, S., Boaventura, R.A.R., Brillas, E., Vilar, V.J.P., 2014. Degradation of the antibiotic trimethoprim by electrochemical advanced oxidation processes using a carbon-PTFE air-diffusion cathode and a boron-doped diamond or platinum anode. Appl. Catal. B Environ. 160-161, 492-505.

Moreira, F.C., Boaventura, R.A.R., Brillas, E., Vilar, V.J.P., 2017. Electrochemical advanced oxidation processes: a review on their application to synthetic and real wastewaters. Appl. Catal. B Environ. 202, 217-261.

Muñoz, I., Rodríguez, A., Rosal, R., Fernández-Alba, A.R., 2009. Life cycle assessment of urban wastewater reuse with ozonation as tertiary treatment: a focus on toxicity-related impacts. Sci. Total Environ. 407, 1245-1256.

Nogueira, R.F.P., Oliveira, M.C., Paterlini, W.C., 2005. Simple and fast spectrophotometric determination of $\mathrm{H}_{2} \mathrm{O}_{2}$ in photo-Fenton reactions using metavanadate. Talanta $66,86-91$.

Özcan, A., Şahin, Y., Koparal, A.S., Oturan, M.A., 2008. Propham mineralization in aqueous medium by anodic oxidation using boron-doped diamond anode. Experimental parameters' influence on degradation kinetics and mineralization efficiency. Water Res. 42, 2889-2898.

Panizza, M., Cerisola, G., 2009. Direct and mediated anodic oxidation of organic pollutants. Chem. Rev. 109, 6541-6569.

Pérez-Estrada, L.A., Malato, S., Agüera, A., Fernández-Alba, A.R., 2007. Degradation of dipyrone and its main intermediates by solar AOPs: identification of intermediate products and toxicity assessment. Catal. Today 129, 207-214.

Persoone, G., Marsalek, B., Blinova, I., Torkokne, A., Zarina, D., Manusadzianas, L., Nalecz-Jawecki, G., Tofan, L., Stepanova, N., Tothova, L., Kolar, B., 2003. A practical and user-friendly toxicity classification system with microbiotests for natural waters and wastewaters. Environ. Toxicol. 18, 395-402.

Prieto-Rodríguez, L., Oller, I., Klamerth, N., Agüera, A., Rodríguez, E.M., Malato, S., 2013. Application of solar AOPs and ozonation for elimination of micropollutants in municipal wastewater treatment plant effluents. Water Res. 47, 1521-1528.
Rabaaoui, N., Saad, M.E.K., Moussaoui, Y., Allagui, M.S., Bedoui, A., Elaloui, E., 2013. Anodic oxidation of o-nitrophenol on BDD electrode: variable effects and mechanisms of degradation. J. Hazard. Mater. 250-251, 447-453.

Santos, P.M.P., Antunes, A.M.M., Noronha, J., Fernandes, E., Vieira, A.J.S.C., 2010 Scavenging activity of aminoantipyrines against hydroxyl radical. Eur. J. Med. Chem. 45, 2258-2264.

Savic, I.M., Savic Iva, M.M., Stojiljkovic, S.T., Gajic, D.G., 2014. Modeling and optimization of energy-efficient procedures for removing lead(II) and zinc(II) ions from aqueous solutions using the central composite design. Energy 77, 66-72.

Singh, B., Kumar, R., Ahuja, N., 2004. Optimizing drug delivery systems using systematic "Design of Experiments" part I: fundamental aspects. Crit. Rev. Ther. Drug Carrier Syst. 22, 27-105.

Sirés, I., Brillas, E., Oturan, M.A., Rodrigo, M.A., Panizza, M., 2014. Electrochemical advanced oxidation processes: today and tomorrow. A review. Environ. Sci. Pollut. Res. 21, 8336-8367.

Steter, J.R., Brillas, E., Sirés, I., 2016. On the selection of the anode material for the electrochemical removal of methylparaben from different aqueous media. Electrochim. Acta 222, 1464-1474.

Tay, K.S., Madehi, N., 2015. Ozonation of ofloxacin in water: by-products, degradation pathway and ecotoxicity assessment. Sci. Total Environ. 520, 23-31.

Thiam, A., Brillas, E., Centellas, F., Cabot, P.L., Sirés, I., 2015. Electrochemical reactivity of Ponceau 4R (food additive E124) in different electrolytes and batch cells. Electrochim. Acta 173, 523-533.

Thiam, A., Sirés, I., Garrido, J.A., Rodríguez, R.M., Brillas, E., 2015. Decolorization and mineralization of Allura Red AC aqueous solutions by electrochemical advanced oxidation processes. J. Hazard. Mater. 290, 34-42. 